\title{
STRATEGIC RESTRUCTURING OF SELF-HELP GROUPS - A SWOT ANALYSIS (A CASE STUDY WITH SPECIAL REFERENCE TO KERALA, INDIA)
}

\author{
Dr . Rahumathunza .I ${ }^{1}$
}

ABSTRACT: The effect of Self-Help Groups (SHGs) on poverty and women empowerment in developing countries is well recognized. However, one of the major problems confronted by the SHGs in Kerala is their long run sustainability. The study attempts to identify the operational issues in the functioning of SHGs and aims at suggesting strategies for the restructuring of SHGs formed between 1999 and 2007. It is found that the women in rural areas stand to benefit from the formation of SHGs in terms of socioeconomic empowerment. However, women entrepreneurs still struggle to sustain their business prospects. The SWOT and TOWS analyses of this have also confirmed the findings. It is suggested that groups doing similar activities should have common facility centers. The monetary incentives to SHGs should be linked with the quality aspects of the enterprise. The study concludes by providing an insight into the long-term sustainability aspect of the enterprise.

Key Words: Self-Help Groups (SHGs), sustainability, India, Kerala, long run sustainability, socioeconomic, micro-finance, women empowerment, poverty alleviation, SWOT and TOWS.

\section{INTRODUCTION}

Income generating activities can play an important role in improving the quality of life, smoothing away of seasonal fluctuations in household income as well as helping in generating entrepreneurial skill among women folk. Further, it is ideal for employment generation. Most women, conforming to the conventional and traditional roles, accept domestic responsibilities as mothers and wives. The development of income generating activities can help to create immediate employment opportunities by involving women at a lower investment level. Besides, it provides full utilization of capital and reduces the wastage of human resources particularly of women. The Self-Help Group (SHG) programmes in almost all the developing and underdeveloped countries are playing a vital role in rural development and the empowerment of rural women in their respective regions.

\footnotetext{
${ }^{1}$ Professor, Department Of Mechanical Engg, Mes College Of Engg, Kuttippuram, Kerala, India-679573
} 


\section{EMPOWERMENT OF WOMEN}

The SHG development programme is aimed at the empowerment of women from the socioeconomic point of view. Reports indicate that SHG programmes, often in the form of savings and credit or micro-credit schemes, have succeeded in changing the lives of poor women and generating positive factors such as increased social status and empowerment. Recently, a number of studies have focused on the difficult but vital problem of measuring empowerment. Empowerment is comprised of two sub-components. The first one consists of opportunities to convey information on institutional possibilities open to a person or a community, using accessible data, service provision, and so on. The second one is that of agency. At the individual level, agency is an assessment of "what a person can do in line with his or her conception of the good" (Alsop, 2005). Empowerment can take place at a hierarchy of different levels, that is, individual, household, community, and societal and is facilitated by providing encouraging factors, for example exposure to new activities, which can build capacities and removing inhibiting factors, for example, lack of resources and skills.

\section{WOMEN PARTICIPATION IN MICRO-ENTREPRENEURIAL ACTIVATES}

The participation of women in economic activities is often considered as the important factor in the economic and the social empowerment aspects of women. Duly recognizing the importance and the involvement of women in participatory model of development, both the Central and the State Governments in India have taken up the theme of women empowerment as one of the main agendas to tackle poverty and many socioeconomic issues. With over 700 million women living in poverty around the world, micro-finance and enterprise promotion programmes through SHGs is seen as an essential tool for poverty alleviation.

Small groups of women by working out of their homes make pickles, pappads, garments, or deal in stationery, or do binding or tailoring, and the list can be endless. It can lead to more ambitious projects and businesses, requiring a range of skills in design, production, and marketing innovations. Women SHGs have contributed significantly to the economic development of the country. In brief, SHGs facilitate the coming together of women as economic entrepreneurs to ensure an additional income. And, in the process, it creates a heightened sense of awareness and confidence in their role by contributing to the family income and ultimately to the rural economy.

The socioeconomic background of women in rural areas examines the factors which have motivated the women to become SHG members and eventually entrepreneurs. The study analyzes the nature of economic activities and the performance in terms of growth indicators such as investment turnover, employment, capacity utilization, sources of finance, marketing, and other related aspects and identifies the problems faced by SHG women in running the enterprises and suggests policy measures to rectify the same.

\section{STATEMENT OF THE PROBLEM}

In Kerala, the SHGs engaged in production oriented activities are below 30\% of the micro enterprises started under the micro-credit programme of National Bank for Agriculture and Rural Development (NABARD Report, 2002). The most striking limitation of the SHG programme in Kerala is that not many out of 1, 51, 406 neighbourhood groups formed across the different districts of Kerala are able to run viable micro enterprises. This fact raises the important question of why certain groups are functioning well while others are not, given the identical 
organizational as well as institutional framework for all the groups. The differences appear to be owing to the local set up in which the group is operating. The initial endowments of the members of the group like higher educational qualifications, artisan skills as well as connections to the mainstream social networks, and the effectiveness of local Government intervention in the group activities in the local area, are the factors influencing the functioning of the groups. The replication of the same activity in a number of groups aggravates the extant problems of marketing. It is to be examined whether these factors are responsible for the differences in the functioning of the groups. A separate study on this issue is needed to correct the loopholes of the existing system (Human Development Report, 2005).

The study focuses on this issue and identifies it as the research gap. The problems in the SHGs start from their project identification to the marketing of goods and the services level. The programmes have resulted in the empowerment of women but in the sustainability aspect of the enterprise, it has not shown a positive outcome. Therefore, the current study aims at framing a strategic restructuring plan for the operation and the functioning of the micro enterprises promoted by the SHGs in the State of Kerala. The first part of the study broadly defines and analyse various aspects of development and functioning of SHG s in the country. In the second part a SWOT analysis is carried out to arrive at a TOWS matrix to generate strategies for the sustainable existence of the microenterprises promoted by the SHGs in Kerala.

\subsection{Objective of the Study}

After conducting a broad literature review and identifying the gap, the objectives of the study have been finalized and as follows:

(i) Study and analyze the group dynamics exhibited in the SHGs.

(ii) Scrutinize and analyze the operational problem faced by the women micro enterprises promoted by the SHGs.

(iii) Identify the sustainability aspects of the enterprises, the SHGs and suggest strategic plan for the restructuring of the SHGs with respect to their operation and functioning in the long run

\subsection{Research Methodology}

The SHGs selected for the study were formed between 1999 and 2007 with at least two years of existence from the date of registration. Stratified random sampling is used for the data collection. A sample size of two hundred and ninety four SHGs is selected for the survey. A well-structured questionnaire is designed for collecting the data. The primary data has been collected from SHGs engaged in various types of micro enterprises activities. The secondary data has been drawn from different sources like the District Rural Development Agency (DRDA), NABARD, Census of India Reports, and Economic Review of the State Planning Board. Statistical analyses are conducted with the help of SPSS version-16 statistical software. Similarly, SWOT and TOWS analyses were also done. The results obtained from the analysis are used in reaching various conclusions.

\section{RESULTS AND DISCUSSIONS}

SHGs have proven to be a profitable business for micro financing institutions in rural and semiurban areas in India and they consider lending to SHGs as a business opportunity. The growth of Microfinance sector in India has been significant over last two decades. There exist different approaches and models of microfinance; the most predominant in operation among them is the 
Self-Help Group (SHG) model. The SHG interventions in the country have reached out to more than 17 million households, becoming the largest microfinance endeavors in the world in terms of outreach in spite of the remarkable achievement of the SHG movement in the country. However, sustainability of the SHGs continues to be a major concern (Rahumathunza, I., and Krishnankutty, K.V)

This section of the study briefly discusses the various aspects of the enterprise selection made by the groups and its influence on women empowerment. The following table shows the details of the micro enterprises (economic activities) started by SHGs surveyed.

Table 1 Economic Activities Started by SHGs

\begin{tabular}{|l|l|l|l|}
\hline Sl. No. & $\begin{array}{l}\text { Type of economic activities identified } \\
\text { and started }\end{array}$ & $\begin{array}{l}\text { No. } \\
\text { respondents }\end{array}$ & Percentage \\
\hline 1. & Industry & 138 & 46.94 \\
\hline 2. & Service & 83 & 28.23 \\
\hline 3. & Business & 56 & 19.05 \\
\hline 4. & Others & 17 & 5.78 \\
\hline & Total & 294 & 100 \\
\hline
\end{tabular}

Chart 1

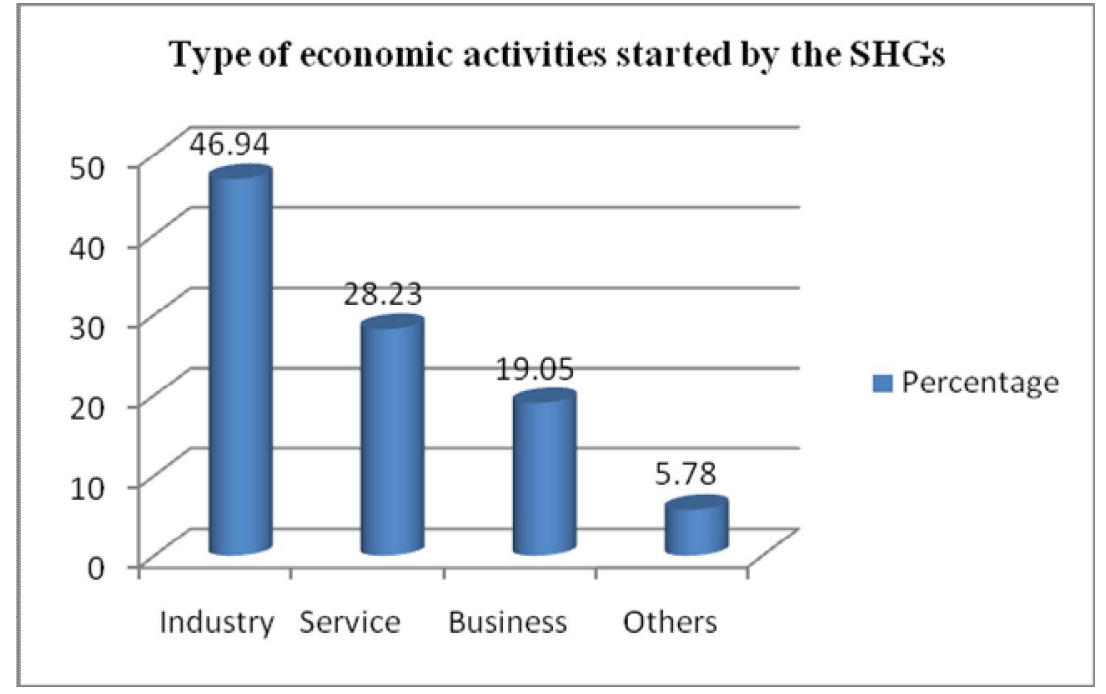

Table 1 presents the economic activities started by the SHGs. Of the 294 groups surveyed, 46.94\% have started manufacturing based micro enterprises, $28.23 \%$ have started service activities, $19.05 \%$ have started business, and the remaining $5.78 \%$ are involved in other activities. The reasons for starting the enterprises as reported and ranked by the respondents are also analyzed further. 
Table 2

Reasons for Starting Economic Activities

\begin{tabular}{|l|l|l|l|l|}
\hline \multirow{2}{*}{$\begin{array}{l}\text { Reasons for starting the } \\
\text { economic activity }\end{array}$} & \multicolumn{4}{l}{$\begin{array}{l}\text { Ranks and percentage of respondents doing different type of } \\
\text { economic activities }\end{array}$} \\
\cline { 2 - 5 } & Industry & Service & Business & Other activities \\
\hline $\begin{array}{l}\text { Availability of skilled } \\
\text { manpower }\end{array}$ & $3(35.5)$ & $5(73.5)$ & $6(58.9)$ & $5(47.1)$ \\
\hline Availability of raw material & $2(32.6)$ & $6(54.2)$ & $2(60.7)$ & $3(35.3)$ \\
\hline Low capital investment & $1(32.6)$ & $3(45.8)$ & $1(60.7)$ & $7(35.3)$ \\
\hline Assistance from DRDA & $4(27.5)$ & $7(61.4)$ & $7(91.1)$ & $7(47.1)$ \\
\hline Market potential & $1(35.5)$ & $4(43.4)$ & $3(58.9)$ & $1(41.2)$ \\
\hline Unemployment & $6(42.0)$ & $2(62.7)$ & $4(60.7)$ & $2(41.2)$ \\
\hline Family advice & $8(38.4)$ & $8(63.9)$ & $8(92.9)$ & $8(76.5)$ \\
\hline NGO encouragement & $8(42.0)$ & $9(62.7)$ & $9(73.2)$ & $6(35.3)$ \\
\hline $\begin{array}{l}\text { Employment opportunities } \\
\text { for family members }\end{array}$ & $9(34.1)$ & $1(61.4)$ & $5(60.7)$ & $1(35.3)$ \\
\hline Other reasons & $10(84.1)$ & $10(98.8)$ & $10(98.2)$ & $10(94.1)$ \\
\hline Total [294(100)] & $138(46.94)$ & $83(28.23)$ & $56(19.05)$ & $17(5.78)$ \\
\hline Source: Primary data & & & \\
\hline
\end{tabular}

Source: Primary data (Figures inside the parentheses indicate total percentage of respondents and figures without parentheses indicate the highest rank as provided by the respondents except for the last row, which indicates the activity-wise total)

Table 2 is about the reasons in starting the enterprises by the groups. One can conclude that the low capital investment and the market potential are the major reasons for starting the enterprises under the industry category and is reported as rank one. In the service sector, the same rank is marked for the reason of employment opportunities for family members. The low capital investment is seen as the major reason for selecting business related activities. For other activities, the market potential and employment opportunities for family members are the predominant reasons for the selection of activities.

It is further analyzed the strength, weakness, opportunities and threat (SWOT) aspects of the socioeconomic empowerment part of women in rural areas taking in to consideration the various factors discussed above, which are influencing the socioeconomic empowerment of rural women through their participation in SHGs. These aspects will also help in analyzing the situation and in formulating a long-term strategy for the functioning of the SHG.

Table 3 presents the internal and external aspects of the functioning of SHGs in terms of SWOT analysis. It describes Internal and External Factor Analysis Summary (IFAS and EFAS) of the SWOT. The variables have been tested in the scale of 1-5 (Very high to Very Low).

Table 3 Internal Factor Analysis Summaries (IFAS) and Strength and Weakness Identified

\begin{tabular}{|l|l|l|l|l|lr|}
\hline $\begin{array}{l}\text { Sl. } \\
\text { No. }\end{array}$ & $\begin{array}{l}\text { Internal factors } \\
\text { strength/weakness }\end{array}$ & Weight & Rating & $\begin{array}{l}\text { Weighted } \\
\text { score }\end{array}$ & Comment \\
\hline Strength \\
\hline 1. & $\begin{array}{l}\text { Availability of skilled } \\
\text { manpower }\end{array}$ & 0.08 & 3 & 0.24 & $\begin{array}{l}\text { Inherent strength of } \\
\text { Kerala }\end{array}$ \\
\hline
\end{tabular}




\begin{tabular}{|c|c|c|c|c|c|}
\hline 2. & $\begin{array}{l}\text { Availability of raw } \\
\text { material }\end{array}$ & 0.07 & 2 & 0.14 & $\begin{array}{l}\text { Inherent strength of } \\
\text { Kerala }\end{array}$ \\
\hline 3. & Low capital investment & 0.08 & 3 & 0.24 & Being micro enterprises \\
\hline 4. & $\begin{array}{l}\text { Availability of DRDA } \\
\text { and NGOs assistance }\end{array}$ & 0.08 & 3 & 0.24 & $\begin{array}{l}\text { Strength to } \text { SHG } \\
\text { functioning }\end{array}$ \\
\hline 5. & Market potential & 0.09 & 4 & 0.36 & Consumer oriented \\
\hline 6. & $\begin{array}{l}\text { Employment } \\
\text { opportunities }\end{array}$ & 0.08 & 3 & 0.24 & $\begin{array}{l}\text { Inherent strength of } \\
\text { Kerala }\end{array}$ \\
\hline 7. & Family advice & 0.08 & 3 & 0.24 & $\begin{array}{l}\text { Advantages of support } \\
\text { system }\end{array}$ \\
\hline 8. & NGO encouragement & 0.09 & 4 & 0.36 & $\begin{array}{l}\text { Strength to } \\
\text { functioning }\end{array}$ \\
\hline 9. & $\begin{array}{l}\text { Employment } \\
\text { opportunities for family } \\
\text { members }\end{array}$ & 0.09 & 4 & 0.36 & $\begin{array}{l}\text { Key benefits of SHG } \\
\text { operations }\end{array}$ \\
\hline 10. & Literacy and education & 0.09 & 4 & 0.36 & $\begin{array}{l}\text { Strength to } \mathrm{SHG} \\
\text { functioning }\end{array}$ \\
\hline \multicolumn{6}{|c|}{ Weakness } \\
\hline 11. & $\begin{array}{l}\text { Lack of group } \\
\text { coordination }\end{array}$ & 0.06 & 3 & 0.18 & Major weakness \\
\hline 12. & $\begin{array}{l}\text { Conflict within the } \\
\text { group }\end{array}$ & 0.04 & 2 & 0.08 & Lack of education \\
\hline 13. & $\begin{array}{l}\text { Problems in financial } \\
\text { dealing }\end{array}$ & 0.02 & 1 & 0.02 & $\begin{array}{l}\text { Lack of knowledge on } \\
\text { sources of finance }\end{array}$ \\
\hline 14. & $\begin{array}{lll}\text { Insufficient loans from } \\
\text { SHGs }\end{array}$ & 0.11 & 4 & 0.44 & Internal conflicts \\
\hline 15. & $\begin{array}{l}\text { Default on loans from } \\
\text { SHG }\end{array}$ & 0.02 & 1 & 0.02 & More family burdens \\
\hline 16. & $\begin{array}{l}\text { Delay in getting the } \\
\text { loans from SHG }\end{array}$ & 0.01 & 1 & 0.01 & 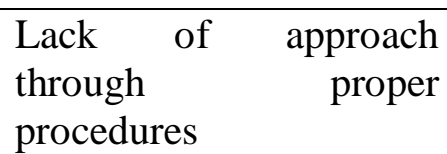 \\
\hline & Total & 1 & - & 3.17 & -- \\
\hline
\end{tabular}

Source: Primary data

The total weighted score 3.17 indicates that the functioning of SHGs is efficient in its average performances and it is vigorous rather than weak, which shows that the SHGs could function in a sustainable form in the near future.

Table 4: External Factor Analysis Summary (EFAS) and Opportunities and Threats Identified

\begin{tabular}{|l|l|l|l|l|l|}
\hline Sl. No. & External factors & Weight & Rating & $\begin{array}{l}\text { Weighted } \\
\text { score }\end{array}$ & Comment \\
\hline Opportunities & Self-confidence & 0.03 & 4 & 00.12 & $\vdots \Xi \Xi \approx+$ \\
\hline 1.
\end{tabular}




\begin{tabular}{|c|c|c|c|c|c|}
\hline 2. & $\begin{array}{l}\text { Hopes for better standard of } \\
\text { living }\end{array}$ & 0.02 & 2 & 0.04 & \\
\hline 3. & Better status in the family & 0.02 & 2 & 0.04 & \\
\hline 4. & Communication skill & 0.03 & 3 & 0.09 & \\
\hline 5. & Enhancing leadership Skills & 0.03 & 3 & 0.09 & \\
\hline 6. & Knowledge of credit management & 0.03 & 3 & 0.09 & \\
\hline 7. & Public relations & 0.02 & 2 & 0.04 & \\
\hline 8. & Economic independence & 0.02 & 2 & 0.04 & \\
\hline 9. & Social cohesion & 0.03 & 3 & 0.09 & \\
\hline 10. & Self-expression--decision making & 0.02 & 2 & 0.04 & \\
\hline \multicolumn{6}{|c|}{ Threats } \\
\hline 11. & Lack of coordination & 0.07 & 2 & 0.14 & \multirow{10}{*}{ 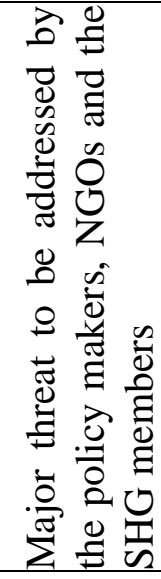 } \\
\hline 12. & Not result oriented & 0.07 & 2 & 0.14 & \\
\hline 13. & Time management lacking & 0.08 & 3 & 0.24 & \\
\hline 14. & $\begin{array}{l}\text { Tendency to utilize money for } \\
\text { other purposes }\end{array}$ & 0.08 & 3 & 0.24 & \\
\hline 15. & Personal problems & 0.07 & 2 & 0.14 & \\
\hline 16. & Social problems & 0.10 & 5 & 0.5 & \\
\hline 17. & Economic problems & 0.09 & 4 & 0.36 & \\
\hline 18. & Technical problems & 0.10 & 5 & 0.5 & \\
\hline \multirow[t]{2}{*}{19.} & Marketing problems & 0.10 & 5 & 0.5 & \\
\hline & Total & 1 & - & 3.44 & \\
\hline
\end{tabular}

Source: Primary data

The total weighted score 3.44 is greater than the industry averages of 3 (Hunger, 1999). The threats faced by the SHG women in the study area have to be addressed effectively so that the opportunities can be converted into possible business strength. A "TOWS" on the above factors are further analyzed and some conclusions are drawn.

\subsection{TOWS Analysis of the Empowerment of Rural Women through SHGs}

From the above discussion one can clearly understand that women's empowerment, like poverty eradication, and sustainability of SHGs functioning, cannot possibly be within the purview of a single organization. Moreover, the SHG entrepreneurs have to push themselves and their participants to examine the environment in which they can work, generate networks and partnerships to support change, and to harness parallel social movements of poverty alleviation and economic empowerment of rural women. One way of understanding the concept is to design appropriate strategies through an effective TOWS matrix and strategy formulation in combination of strength/opportunities (SO) with the measures to correct the weakness and overcome the threats faced by the women SHGs. Table 5 presents the results. 
Table 5 TOWS Matrix

\begin{tabular}{|c|c|c|}
\hline Internal factors & Strength (s) & Weakness (W) \\
\hline $\begin{array}{l}\text { External } \\
\text { (EFAS) }\end{array}$ & $\begin{array}{l}\text { S1. Availability of skilled } \\
\text { manpower } \\
\text { S2. Availability of raw material } \\
\text { S3. Low capital investment } \\
\text { S4. Availability of DRDA and } \\
\text { NGO assistance } \\
\text { S5. Market potential } \\
\text { Employment } \\
\text { opportunities } \\
\text { S6. Family advice } \\
\text { S7. NGO encouragement } \\
\text { S8. Employment opportunities } \\
\text { for family members }\end{array}$ & $\begin{array}{l}\text { W1. Lack of group coordination } \\
\text { W2. Conflict within the group } \\
\text { W3. Problems in financial } \\
\text { dealing } \\
\text { W4. Autonomy of leaders } \\
\text { W5. Insufficient loans from } \\
\text { SHGs } \\
\text { W6. Default on loans from SHGs } \\
\text { W7. Delay in getting the loans } \\
\text { from SHG }\end{array}$ \\
\hline
\end{tabular}

\begin{tabular}{|c|c|c|}
\hline Opportunities (O) & SO Strategies & WO Strategies \\
\hline $\begin{array}{l}\text { O1. Self-confidence } \\
\text { O2. Hopes for better } \\
\text { standard of living } \\
\text { O3. Better status in the } \\
\text { family } \\
\text { O4. Communication } \\
\text { skill } \\
\text { O5. Enhancing } \\
\text { leadership skills } \\
\text { O6. Knowledge of credit } \\
\text { management } \\
\text { O7. Good public } \\
\text { relations } \\
\text { O8. Economic } \\
\text { independence } \\
\text { and social cohesion } \\
\text { 09. Self-expression-- } \\
\text { decision making }\end{array}$ & 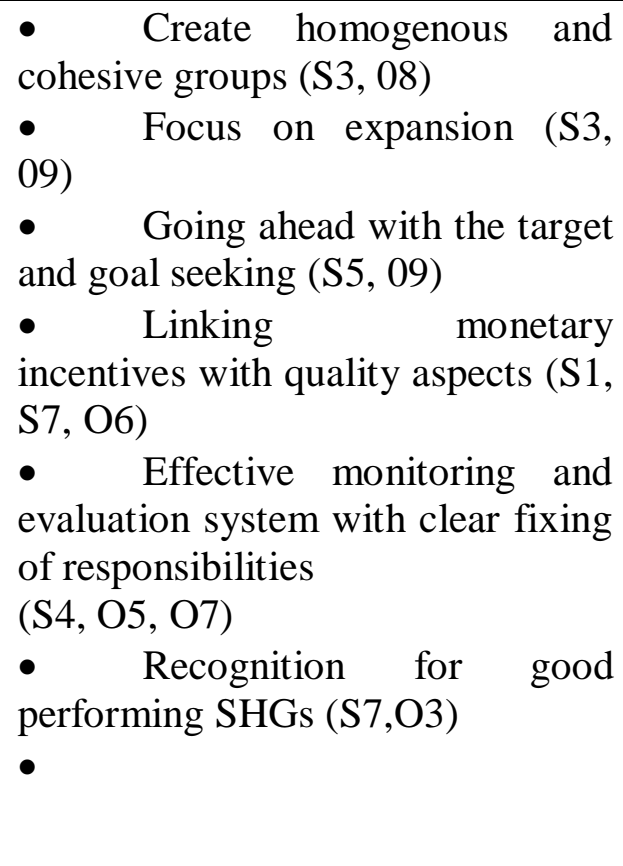 & $\begin{array}{l}\text { Periodic grading of SHGs } \\
\text { by external agency (W2, O2) } \\
\text { Support for both } \\
\text { individual as well as group } \\
\text { economic activity (W1, O1) } \\
\text { f Avoid compulsion to go } \\
\text { for 'group' economic activity } \\
\text { where there is lack of group } \\
\text { consensus, common interest, and } \\
\text { skills (W4, O2) } \\
\text { - Concept of 'activity based } \\
\text { groups' to be explored for } \\
\text { likeminded members across } \\
\text { different groups (W2, O6) } \\
\text { Orientation to cover new } \\
\text { groups as well as new members in } \\
\text { existing groups (W1,O9) }\end{array}$ \\
\hline Threats (T) & ST & WT \\
\hline $\begin{array}{l}\text { T1. Lack of coordination } \\
\text { T2. Not result oriented } \\
\text { T3. Time management } \\
\text { lacking } \\
\text { T4. Tendency to utilize } \\
\text { money for other } \\
\text { purposes } \\
\text { T5. Personal problems } \\
\text { T6. Social problems }\end{array}$ & $\begin{array}{l}\text { - Need for standardization of } \\
\text { certain SHG systems and processes } \\
\text { while maintaining flexibility- } \\
\text { auditing, format of final accounts } \\
(\mathrm{S} 4, \mathrm{~T} 4) \\
\text { - Guidelines on certain } \\
\text { aspects-tenure of office bearers, } \\
\text { regularity of elections, number of } \\
\text { posts to be held by an individual }\end{array}$ & $\begin{array}{l}\text { 1. Combination of external } \\
\text { and internal monitoring (W2,T1) } \\
2 . \quad \text { Additional support in } \\
\text { terms of capacity building, } \\
\text { linkages, marketing/know-how } \\
(\mathrm{W} 1, \mathrm{~T} 8, \mathrm{~T} 9)\end{array}$ \\
\hline
\end{tabular}


T7. Economic problems T8. Technical problems T9. Marketing problems
$(\mathrm{S} 1, \mathrm{~T} 1)$

- $\quad$ Effective and pro-active monitoring system to be in place $(\mathrm{S} 6, \mathrm{~T} 4)$

As already mentioned, TOWS matrix is created in combination of strength/opportunities with the measures to overcome the weakness and threats. Adequate care is taken to develop strategies that can be well suited to the enterprises of women SHGs, where their internal strength and social empowerment can be skillfully clubbed together in strengthening their business skills in support with various external agencies. These strategies are developed keeping in mind the fact that women SHG's awareness level of business tactics such as project identification, marketing, sales promotion, accounting and bookkeeping capabilities are low, that they lack educational support and, moreover, that they are economically backward and mostly trained as unskilled labourers. In order to find the respondents perception towards the sustainability of SHGs the following analysis were made and the necessary recommendations were made for their success in near future.

Table 6 The Opinion of Members on Sustainability of the Enterprise

\begin{tabular}{|l|l|l|l|}
\hline Sl. No & $\begin{array}{l}\text { Whether the activity undertaken is } \\
\text { sustainable or not }\end{array}$ & No. of respondents & Percentage \\
\hline 1. & Yes & 69 & 23.47 \\
\hline 2. & No & 225 & 76.53 \\
\hline & Total & 294 & 100 \\
\hline
\end{tabular}

Source: Primary data

Table 6 provides the data on the opinion of members on the sustainability of the activities undertaken by the groups. Of the 294 members surveyed, $76.53 \%$ are of the opinion that the activity in which their groups are involved is not sustainable at present and the remaining $23.47 \%$ assert that the activity in which they take part is sustainable. Thus, the data presented in the table amply prove that the activities undertaken by the majority of groups are not sustainable at present. Table 5.98 depicts the opinion of members on sustainability of their groups and their activities on a long-term basis.

Table 7 Members' Opinion on Sustainability of Groups and Their Activity on a Long-Term Basis

\begin{tabular}{|l|l|l|l|}
\hline \multirow{2}{*}{ Activity } & \multicolumn{2}{|l|}{$\begin{array}{l}\text { Opinion on whether the activity is sustainable on a long- } \\
\text { term basis }\end{array}$} & \multirow{2}{*}{ Total } \\
\cline { 2 - 3 } & Yes & No & \\
\hline Industry & $97(70.3)$ & $41(29.7)$ & $138(100)$ \\
\hline Service & $48(57.8)$ & $35(42.2)$ & $83(100)$ \\
\hline Business & $33(58.9)$ & $23(41.1)$ & $56(100)$ \\
\hline Others & $8(47.1)$ & $9(52.9)$ & $17(100)$ \\
\hline Total & $186(63.3)$ & $108(36.7)$ & $294(100)$ \\
\hline
\end{tabular}

Source: Primary data (Figures inside the parentheses indicate column total percentage of the nature of activity)

An analysis of the data presented in table 7 shows the opinion of the SHG members on long-term sustainability of their groups and activities. Of the 294 members surveyed, $63.3 \%$ believe that their groups and activities can sustain in the long-term, whereas $36.7 \%$ of them do not believe so. 
Thus, it is clear that $63.3 \%$ of the members surveyed are of the opinion that their enterprises can be made sustainable in the long-term basis.

\section{CONCLUSIONS}

The study shows that the operational problems faced by the SHG are mainly related to the nature of their economic activities. The SHGs are almost homogeneous in nature with respect to their organizational structure and heterogeneous with respect to their type of activities and production line. Therefore, the strategies worked out are based on the concept of grand strategy by clubbing the internal and external factors in the functioning of SHGs with "SWOT" and "TOWS" matrices in arriving at the "SO", "ST", "WO", and "WT" strategies. The strategies are also developed keeping in mind the fact that the women SHGs' awareness level of business tactics such as project identification, marketing, sales promotion, accounting capabilities are low, and that they are economically backward and mostly trained as unskilled labourers. It is found that groups can sustain in the long run through the enhancing functional viability of SHGs.

\section{RECOMMENDATIONS}

The programme of SHG formation and development has played a significant role in improving the social status of women in rural areas. More attention is required to be given for enhancing the economic status of rural women. This could be achieved only through the involvement of groups in sustainable economic activities. The economic activities undertaken by the groups are not seen sustainable due to various extraneous factors. Since the target population studied comes under the rural development initiative of the Government under the plan scheme, the stake holders of the programme studied will be the Central and State Governments, monitoring agencies such as DRDA and NABARD, financial institutions, and the SHGs. Therefore, the recommendations made in the study are also targeted for the benefit of these stake holders. The following recommendations are made for the future course of action based on the findings of the study.

- $\quad$ Members in the age group of 30 to 50 years should be encouraged to join the SHGs for the formation of better performing groups.

- SHG members need technical educational support and training. The DRDA and NABARD should initiate industry- institute interaction programmes to impart such trainings. Industrial Training Institutes and Industrial Training Centers (ITIs and ITCs) are functioning under the public and the private sectors in almost all the rural areas of the State. The training to the SHG members on a short term basis will be possible by utilizing the infrastructural facility available with these centers. This can be worked out through the national skill development mission of the Government of India.

- $\quad$ The policy makers both at the Centre and in the State must initiate steps for the supply of basic raw materials to the SHG enterprises at subsidized rates. The Government agencies such as Kerala Small Industries Development Corporation functioning in the State, and National Small Industries Development Corporation functioning at the national level are to be entrusted with this task.

- $\quad$ Agriculture and allied activities are seen as predominant economic activities in the manufacturing sector. The wrong identification and repetition of similar activities affect the sustainability of individual groups and leads to competition between groups. SHGs should be encouraged and educated to identify potentially viable sectors.

- $\quad$ The quality of governance of those nodal agencies that are involved in supporting SHGs 
must be improved by initiating action plans for providing monitory incentives to good working SHGs, imparting periodical training on bookkeeping and accounting to SHGs, and by having a follow up with financial institutions involved in the linkage.

- Monitoring agencies may take effective steps to create awareness of the need for labeling, bar coding, and packaging technologies to stay ahead in the well established wholesale and retail markets.

- The SHG members have to be educated in market extension and market oriented production planning activities and proper training should be given to SHG members in treating marketing as an integral part of business tactics.

- The DRDA must conduct training programmes which can help the SHG women members to learn about the assembling of products and selling the final products at covered auction platforms to the large organized markets including MNCs.

- $\quad$ Clustering of similar activities must be encouraged. There should be a support system with common facility centers. Policy decisions existing for cluster development programmes for the small industry sector at the national level must be made applicable to the clustering of SHGs doing similar activities on the part of the Government and the promoting agencies. Special cluster assistance available for the small scale sector should be extended to SHG's clusters also.

\section{REFERENCES}

[1]. Abhas Kumar Jha, (2004), "Lending to the Poor--Design for Credit", Economic and Political Weekly, Vol. XXXV, No. 8 \& 9, 2004, pp. 56-57.

[2]. Agarwal, K. P., Nagar, I. C., \& Tripathi, D. (1997): Study Report on Micro Credit Delivery to Rural Poor in Bangladesh and Indonesia: Bhumi Sudhar Nigam, Lucknow, U.P, February, 1997, pp. 15-25.

[3]. Alan Bryman, (2008), Social Research Methods, Oxford University press, New York, Pages 19, 238, 535, 539, and 540.

[4]. Alsop, R. \& Heinsohn, N. (2005), "Measuring Empowerment in Practice: Structuring Analysis and Framing Indicators", World Bank Policy Research Working Paper 3510, February 2, 2005, pp. 11-20.

[5]. Datta, S. K. \& Raman, A. (1978), "Can Heterogeneity and Social Cohesion Coexist in Self-Help Groups -An Evidence From Group Lending in AP in India”, Indian Journal of Agricultural Economics, Vol. 33(4), 1978.

[6]. David Hunger, J. \& Thomas, L. Wheelen (1999), Strategic Management, Addison Wesley Longman Inc., 1999, p 107.

[7]. Human Development Report (2005), Centre for Development Studies, Thiruvananthapuram, April, 2005, p 165.

[8]. NABARD, Annual Report 2007, (Available in www.nabard.org).

[9]. Oommen, M. A. (1999), "Community Development Society of Kerala, An Impact Study", Institute of Social Science, New Delhi, pp. 320-360.

[10]. Rahumathunza, I. \& Krishnankutty, K. V. (2009), "Impact Analysis of Energy Management in General Engineering based Micro and Small Enterprise Cluster Consortium", Report of The National Convention of Industrial Engineers \& International Seminar on "Global Energy Challenges: Strategies for Sustainable Development", December, 2008, pp. 40-49.

[11]. Sharma, C. V. \& Ozaki, M. (2003); Asian Development Bank Study No. TAR: IND 36343, "Technical Assistance to India for Preparing the Rural Finance Sector Restructuring and Development Project", December, 2003. 